\title{
Effect of the temperature of waste cooking oil methyl esters on the value of nitrogen oxides emission from the self-ignition engine
}

\author{
Damian Marcinkowski ${ }^{1}$, Mirosław Czechlowski ${ }^{2}$, Weronika Gracz ${ }^{1}$ and Wojciech Golimowski ${ }^{3}$ and Jakub Mazurkiewicz ${ }^{4}$ \\ ${ }^{1}$ Institute of Technology and Life Sciences, Falenty, Hrabska 3, 05-090 Raszyn \\ ${ }^{2}$ Poznań University of Life Sciences, Wojska Polskiego 28, 60-637 Poznań \\ ${ }^{3}$ Wrocław University of Economics, Department of Agroengineering and Quality Analysis, 180/120 Komandorska, 53-345 Wrocław \\ ${ }^{4}$ Poznan University of Life Sciences, The Ecotechnologies Laboratory of the Institute of Biosystems Engineering Wojska Polskiego 50 \\ 60-627 Poznań
}

\begin{abstract}
Combustion of diesel oil and liquid biofuels in self-ignition engines is related to the emission of harmful gases to the atmosphere (i.e. nitrogen, carbon or sulfur oxides). These compounds, emitted in significant quantities, pose a threat to human life and health, as well as to the natural environment. The goal of our research was to investigate the influence of temperature of the waste cooking oil methyl ester on the nitrogen oxides emission in the self-ignition engine. This is to help determine if the use of biofuel thermal activation can be used to reduce nitrogen oxides emissions. Experiments carried out on the test bench in relation to harmful nitrogen compounds $\left(\mathrm{NO}_{\mathrm{x}}\right)$. The emission of exhaust gases from a diesel engine fed with methyl esters of the cooking oil was measured. The measurements were made in accordance with ISO 81784. From the obtained test results it can be concluded that it is worth equipping the engine with installation for preheating the fuel before its injection, but the optimal value of fuel temperature reducing emissions is at least $70^{\circ} \mathrm{C}$.
\end{abstract}

\section{Introduction}

According to forecasts for 2010-2040, the increase in global energy consumption will be around 56\%[1]. Currently, the vast majority of energy is produced as a result of burning fossil fuels, which is associated with the emission of gaseous pollutants, which include carbon oxides, nitrogen and sulphur oxides. Shrinking crude oil reserves and the negative impact of their combustion on the climate and human health have caused an increase in interest in the subject of renewable energy sources (i.e. wind, solar or liquid biofuels) [2-4]. Biodiesel can be produced from a variety of raw materials: edible vegetable oils, unfit oils, post-frying oil or animal fats [5-7]. They are used to power diesel engines that do not require additional modification. Biodiesel can also reduce $\mathrm{CO}_{2}$ emissions by $50 \%$ over the entire life cycle (from feedstock to wheel) [8]. The disadvantage of using biodiesel is that their combustion causes more $\mathrm{NO}_{\mathrm{x}}$ emissions than traditional fossil fuels [9]. Waste cooking oil methyl esters can be successfully used to power CI engines. Because of the lower cost, using WCO methyl esters is more economical than other alternative fuels. The disadvantages of this fuel include high viscosity, higher molar mass and chemical structure that result in inefficient combustion, worse atomization and residue deposition on engine parts [10].

The purpose of the tests described in this publication was to examine the effect of the temperature of the biodiesel burned, obtained from cooking oil, on the concentration of nitrogen oxides $\left(\mathrm{NO}_{\mathrm{x}}\right)$ in the exhaust gas emitted.

\section{Experimental Section}

The test stand was the ATMX 2000 engine dynamometer cooperating with the Yanmar 2TNV70ASA two-cylinder diesel engine, whose parameters were described in an earlier publication [11]. Measurements of exhaust emissions from a diesel engine powered by methyl esters of cooking oil were carried out in accordance with the requirements of ISO 8178-4. The VARIOPlus Industrial exhaust gas analyzer was used to analyze the composition of the exhaust gases. Statistical analysis of the results was performed using the Statistica 6.0 program.

Esterification was carried out in a ratio of waste cooking oil to methanol of 1 : 6 . The catalyst $(1.5 \% \mathrm{w} / \mathrm{w}$

*Corresponding author: d.marcinkowski@itp.edu.pl 
of potassium hydroxide, $\mathrm{KOH}$, by mass of oil) was dissolved in the methanol under stirring and added to the reactor. The reaction continued for 1 hour. After the reaction, mixture was transferred to separator funnel, allowing glycerol to separate by gravity for 24 hours. After that glycerol layer and biodiesel were separated. In next step the excess of methanol was removed from biodiesel by evaporation at. $70^{\circ} \mathrm{C}$.

\section{Experimental}

The purpose of the described tests was to determine the effect of the temperature of the fuel supplying the cogeneration unit on the emission of nitrogen oxides $\left(\mathrm{NO}_{\mathrm{x}}\right)$. Tests with the use of a cogeneration aggregate were carried out in accordance with the D1 test procedure, which is used for engines operating at constant speed. Before measurements the aggregate was warmed up to stabilize the operating parameters. When the engine oil temperature exceeded $80^{\circ} \mathrm{C}$ the first measurement was started. The engine operated according to the nominal rotational speed of the asynchronous motor, i.e. its rotational speed was $3000 \pm 30 \mathrm{rpm}$. The rotational speed was controlled by the ParmSuite computer software. The studies were based on a threephase test. First, the engine was loaded with the maximum torque of $25 \mathrm{Nm}$ for this rotational speed $(100 \%$ load), in the second phase of the test the engine was loaded with $21 \mathrm{Nm}(75 \%)$, while in the third, $14 \mathrm{Nm}$ $(50 \%)$. The testing procedure was the same at each test phase. The entire test phase lasted 10 minutes, of which the engine worked to stabilize the parameters for the first 7 minutes, while data was recorded for the next 3 minutes to obtain measurement results. The composition of emitted exhaust gases was verified every 5 seconds, which gave about 35 measurements for each phase of the test. In total, three tests were performed for three different fuel temperatures, which were 20,40 and $70^{\circ} \mathrm{C}$, respectively. During the measurements, the air temperature ranged from 19.9 to $24.8^{\circ} \mathrm{C}$, and the atmospheric pressure was $1020 \mathrm{hPa}$.

The concentrations of nitrogen oxides $\left(\mathrm{NO}, \mathrm{NO}_{2}\right)$ emitted in the flue gas expressed in $\mathrm{mg} / \mathrm{nm}^{3}$ have been summed up and converted into specific emissions expressed in $\mathrm{g} / \mathrm{kWh}$. Measurements of exhaust gas flow and power generated by the engine in a given test phase were used in these calculations. The following equation was used to calculate the concentrations (A):

$$
N O_{x}\left[\frac{g}{k W h}\right]=\frac{N O_{x}\left[\mathrm{mg} / \mathrm{nm}^{\mathrm{s}}\right]-V\left[\mathrm{~nm}^{\mathrm{s}}\right]}{\mathbf{P}[\mathrm{kw}]-1000}
$$

$\mathrm{NO}_{\mathrm{x}}$ - concentration of nitrogen oxides in exhaust gases,

$\mathrm{V}$ - exhaust gas flow rate,

$\mathrm{P}$ - average power generated by the engine during the test phase

One-way ANOVA significance tests were performed for the results obtained in this way. Thanks to statistical analysis, it was assessed whether changes in fuel temperature have a statistically significant impact on the amount of nitrogen oxides emitted. The dependent variables in this case were the emission of nitrogen oxides, and the independent ones were the fuel temperatures. In the next stage, a summary of average $\mathrm{NO}_{\mathrm{x}}$ emissions was made for each of the fuel temperatures and engine loads. On the basis of this summary, graphs were made of the dependence of nitrogen oxide emissions on fuel temperature for three engine loads. The last stage of the analysis of the results was the calculation of emissions from individual tests carried out for different fuel temperatures. Weighted average calculations were carried out in accordance with ISO 8178-4 for the D1 test. The formula below presents the emission results obtained for individual phases and the corresponding coefficients listed in Table 1.

Weighted average emission for the D1 test

$\mathbf{V}_{\text {av. } 1} \cdot 0.2+\mathrm{V}_{\text {av. } 2} \cdot 0.5+\mathrm{V}_{\text {av. } 3} \cdot 0.3$

where:

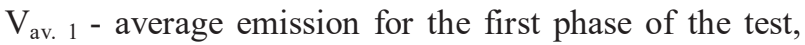
engine load $50 \%$ of the torque,

$\mathrm{V}_{\mathrm{av.} \mathrm{2}}$ - average emission for the first phase of the test, engine load $75 \%$ of the moment,

$\mathrm{V}_{\text {av. 2 }}$ - average emission for the first phase of the test, engine load $50 \%$ of the torque.

Table 1. Calculation factors for average emissions from the D1 test (own study based on: ISO 8178-4).

\begin{tabular}{|c|c|c|}
\hline \multicolumn{3}{|c|}{ Test D1 } \\
\hline $100 \%$ & $75 \%$ & $50 \%$ \\
\hline 0,3 & 0,5 & 0,2 \\
\hline
\end{tabular}

Then, a statistical analysis was performed, whose task was to confirm the statistical significance of changes in $\mathrm{NO}_{\mathrm{X}}$ emissions caused by changes in fuel temperature. For this purpose, one-way ANOVA tests were performed. Three tests were performed, each for a different engine load, respectively: 50\%, 75\% and 100\% of the nominal torque. The following hypotheses were adopted: $\mathrm{H} 0$ - average $\mathrm{NO}_{\mathrm{x}}$ emissions in individual test phases do not differ significantly and $\mathrm{H} 1$ - average $\mathrm{NO}_{\mathrm{x}}$ emissions in individual test phases differ significantly. A significance level of 0.05 was adopted for statistical

where: 
analysis. The results of the statistical tests are given in Table 2.

Table 2. Results of one-way ANOVA test at 50, 75 and 100\% engine load.

\begin{tabular}{|c|c|c|}
\hline Engine load & $\begin{array}{l}\text { Averages } \\
\text { compared }\end{array}$ & Probabilities \\
\hline \multirow{3}{*}{$50 \%$} & $20-40^{\circ} \mathrm{C}$ & 0.445 \\
\hline & $40-70^{\circ} \mathrm{C}$ & 0 \\
\hline & $20-70^{\circ} \mathrm{C}$ & 0 \\
\hline \multirow{3}{*}{$75 \%$} & $20-40^{\circ} \mathrm{C}$ & 0 \\
\hline & $40-70^{\circ} \mathrm{C}$ & 0 \\
\hline & $20-70^{\circ} \mathrm{C}$ & 0 \\
\hline \multirow{3}{*}{$100 \%$} & $20-40^{\circ} \mathrm{C}$ & 0 \\
\hline & $40-70^{\circ} \mathrm{C}$ & 0 \\
\hline & $20-70^{\circ} \mathrm{C}$ & 0 \\
\hline
\end{tabular}

In the case of engine load of $14 \mathrm{Nm}(50 \%)$ and fuelled with a temperature in the range of $20-40^{\circ} \mathrm{C}$, the probability exceeds the adopted significance level of 0.05 . Average exhaust emissions at fuel temperatures of 20 and 40 degrees Celsius and engine load of $14 \mathrm{Nm}$ do not differ significantly, so there is no reason to reject the null hypothesis in favour of the alternative hypothesis. The remaining tests indicate significant differences between the compared average emissions of nitrogen oxides. This allows the null hypothesis to be rejected in favour of the alternative hypothesis at a significance level of 0.05 . After statistical analysis, it can be stated that the fuel temperature has a significant impact on the amount of $\mathrm{NO}_{\mathrm{X}}$ emitted under the conditions of the experiment (excluding one of the cases).

The analysis of the test results was carried out in three load variants, $50 \%, 75 \%$ and $100 \%$ of engine torque, in relation to the three tested fuel temperatures: 20, 40 and $70^{\circ} \mathrm{C}$. The weighted average emissions obtained from the D1 tests carried out in accordance with ISO 8178-4 for three selected fuel temperatures were also compared. Table 3 contains the results of average emissions of nitrogen oxides for the tested fuel temperatures for each of the test phases.

Table 3. Average emissions of nitrogen oxides at the tested temperatures at 50,75 and $100 \%$ load.

\begin{tabular}{|c|c|c|}
\hline \multirow{2}{*}{ Engine load } & $\begin{array}{c}\text { Fuel temperature } \\
{\left[{ }^{\mathbf{0}} \mathbf{C}\right]}\end{array}$ & $\begin{array}{c}\text { Emission of } \\
\mathbf{N O}_{\mathbf{x}}[\mathbf{g} / \mathbf{k W h}]\end{array}$ \\
\hline \multirow{3}{*}{$50 \%$} & $20^{\circ} \mathrm{C}$ & 10.76 \\
\cline { 2 - 3 } & $40^{\circ} \mathrm{C}$ & 10.79 \\
\cline { 2 - 3 } & $70^{\circ} \mathrm{C}$ & 9.99 \\
\hline \multirow{3}{*}{$75 \%$} & $20^{\circ} \mathrm{C}$ & 8.02 \\
\cline { 2 - 3 } & $40^{\circ} \mathrm{C}$ & 8.16 \\
\cline { 2 - 3 } & $70^{\circ} \mathrm{C}$ & 7.63 \\
\hline \multirow{3}{*}{$100 \%$} & $20^{\circ} \mathrm{C}$ & 6.65 \\
\cline { 2 - 3 } & $40^{\circ} \mathrm{C}$ & 6.98 \\
\cline { 2 - 3 } & $70^{\circ} \mathrm{C}$ & 6.22 \\
\hline
\end{tabular}

At engine loads of $14 \mathrm{Nm} \mathrm{(50 \% ),} \mathrm{between}$ temperatures 20 and $40^{\circ} \mathrm{C}$, the significance test showed that the emission values do not differ significantly. In the case of a fuel temperature of $70^{\circ} \mathrm{C}, \mathrm{NO}_{\mathrm{x}}$ emissions decreased by $0.80 \mathrm{~g} / \mathrm{kWh}$ compared to $40^{\circ} \mathrm{C}$, i.e. a decrease of $7.42 \%$. It follows that at a temperature of $40^{\circ} \mathrm{C}$, the emission is constant, and when the fuel temperature is greater than 40 degrees Celsius, the emission decreases.

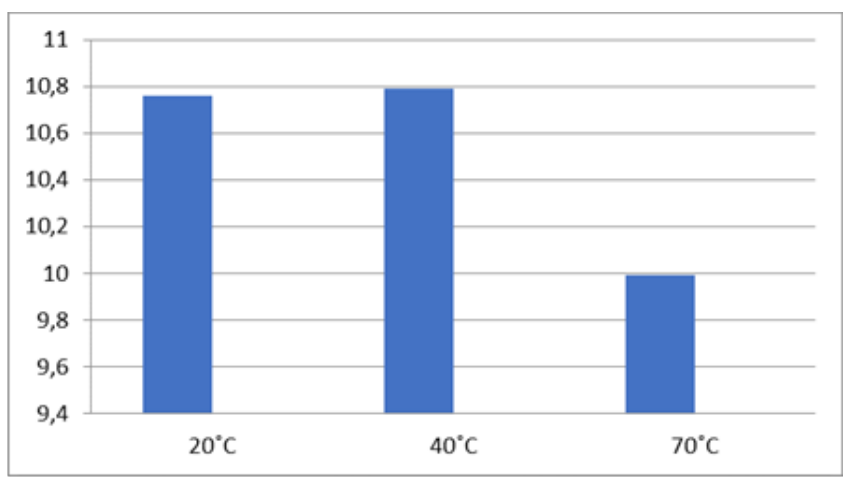

Fig. 1. Impact of fuel temperature on $\mathrm{NO}_{\mathrm{x}}$ emissions at $50 \%$ engine load. 
At engine loads of $21 \mathrm{Nm}(75 \%)$, it has been noted that the increase in fuel temperature from 20 to $40^{\circ} \mathrm{C}$ is accompanied by an increase in nitrogen oxides emissions by $0.14 \mathrm{~g} / \mathrm{kWh}$, or $1.75 \%$. However, when the fuel temperature was $70^{\circ} \mathrm{C}, \mathrm{NO}_{\mathrm{x}}$ emissions decreased by 0.39 $\mathrm{g} / \mathrm{kWh}$ compared to the case when the fuel temperature was set at $20^{\circ} \mathrm{C}$ and by $0.53 \mathrm{~g} / \mathrm{kWh}$ for $40^{\circ} \mathrm{C}$ fuel, which corresponds to emission reductions of $4.87 \%$ and $6.50 \%$. Thus, the same correlation was observed here that was the case with a load of $50 \%$ of the nominal torque.

However, the decrease in emissions found in this case is smaller than for the previous engine load.

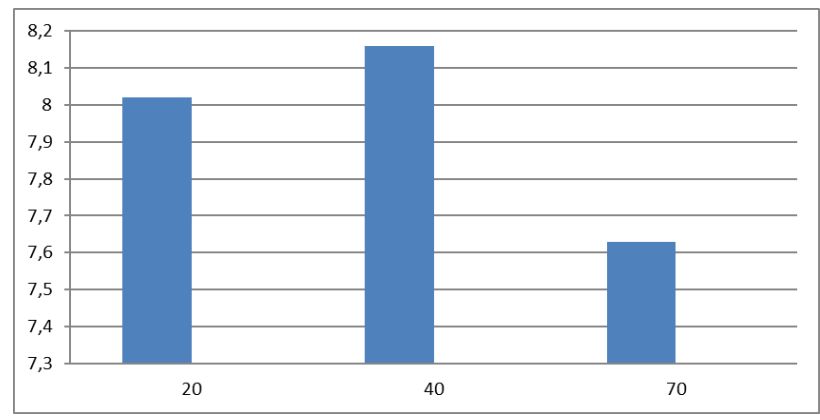

Fig. 2. Impact of fuel temperature on $\mathrm{NO}_{\mathrm{x}}$ emissions at $75 \%$ engine load.

The last test at $100 \%$ load confirmed that at $40^{\circ} \mathrm{C}$ fuel temperature $\mathrm{NO}_{\mathrm{x}}$ emissions increase. With the fuel temperature rising from 20 to $40^{\circ} \mathrm{C}$, nitrogen oxides emissions increased by $0.33 \mathrm{~g} / \mathrm{kWh}$, or $4.96 \%$. However, at $70^{\circ} \mathrm{C}$ fuel temperature, $\mathrm{NO}_{\mathrm{x}}$ emissions decreased compared to 20 and $40^{\circ} \mathrm{C}$ and the same load by $0.43 \mathrm{~g} / \mathrm{kWh}$ and $0.76 \mathrm{~g} / \mathrm{kWh}$, respectively, which corresponds to $6.47 \%$ and $10.89 \%$. The same correlation is shown as for a $75 \%$ load. However, the emission reduction at $100 \%$ load is smaller than at $75 \%$ engine load.

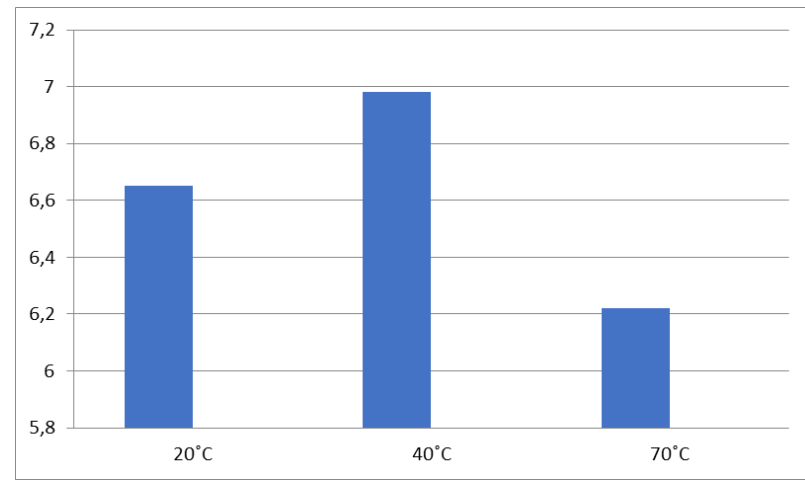

Fig. 3. The effect of fuel temperature on NOx emissions at $100 \%$ engine load.

The last stage of the analysis of changes in nitrogen oxide emissions was the calculation of weighted average emissions for individual D1 tests in accordance with ISO
8178-4. The calculations were carried out in accordance with equation (B), and the results of the calculations are presented in Table 4.

Table 4. Weighted average emissions of nitrogen oxides for the D1 test at the temperatures tested.

\begin{tabular}{|c|c|}
\hline \multicolumn{2}{|c|}{ Weighted average emissions for 3 tests } \\
\hline Temperature & {$[\mathrm{g} / \mathrm{kWh}]$} \\
\hline $20^{\circ} \mathrm{C}$ & 8.157 \\
\hline $40^{\circ} \mathrm{C}$ & 8.332 \\
\hline $70^{\circ} \mathrm{C}$ & 7.679 \\
\hline
\end{tabular}

Weighted average NOx emissions increased by 0.175 $\mathrm{g} / \mathrm{kWh}$, or $2.14 \%$, along with an increase in fuel temperature from 20 to $40^{\circ} \mathrm{C}$. However, a further increase in fuel temperature to $70^{\circ} \mathrm{C}$ results in a significant decrease in emissions by $0.478 \mathrm{~g} / \mathrm{kWh}$ and $0.653 \mathrm{~g} / \mathrm{kWh}$, respectively, i.e. by $6.22 \%$ and $8.50 \%$ compared to 20 and $40^{\circ} \mathrm{C}$ fuel temperature. It is worth noting that a significant increase in fuel temperature above $40^{\circ} \mathrm{C}$ causes a noticeable reduction in the emission of nitrogen oxides from the Yanmar 2TNV70-ASA engine powered with methyl esters of cooking oil.

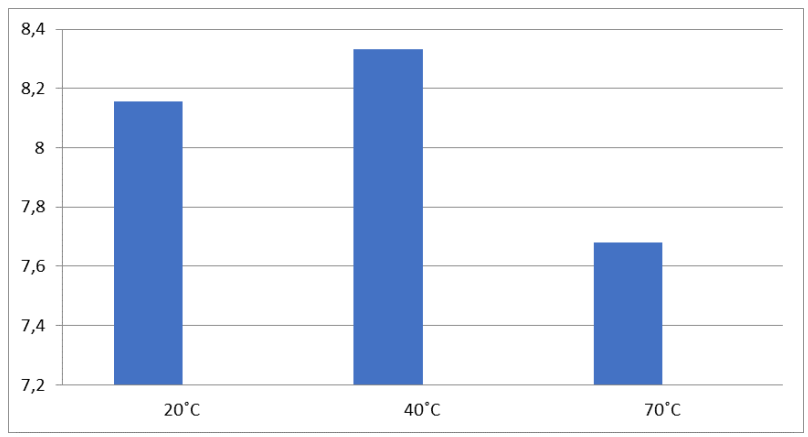

Fig. 4. Weighted average NOx emissions in relation to the fuel temperature under experimental conditions.

\section{Summary}

Fuel temperature rise to $40^{\circ} \mathrm{C}$ with variable loads of 75 and $100 \%$ of the nominal torque, the engine statistically emits a greater amount of nitrogen oxides than when the engine is fuelled at $20^{\circ} \mathrm{C}$. In the case where the fuel temperature is $70^{\circ} \mathrm{C}$, reduced $\mathrm{NO}_{\mathrm{X}}$ emissions have been observed in all tests. It was found that for environmental reasons it is worth equipping the engine with a fuel heating system before its injection, but 
the optimal value of the fuel temperature should be at least $70^{\circ} \mathrm{C}$

\section{Acknowledgements}

Publication is funded by the Polish National Agency for Academic Exchange under the International Academic Partnerships Programme from the project „Organization of the $9^{\text {th }}$ International Scientific and Technical Conference entitled Environmental Engineering, Photogrammetry, Geoinformatics - Modern Technologies and Development Perspectives".

\section{References}

1. D. Y. C. Leung, X. Wu, and M. K. H. Leung, Appl. Energy 87, 1083 (2010)

2. J. Baruah, B. K. Nath, R. Sharma, S. Kumar, R. C. Deka, D. C. Baruah, and E. Kalita, Front. Energy Res. 6, 141 (2018)

3. J. K. Ko and S. M. Lee, Curr. Opin. Biotechnol. 50, 72 (2018)

4. M. Sánchez, F. Bergamin, E. Peña, M. Martínez, and J. Aracil, Fuel 143, 183 (2015)

5. S. Kanakraj and S. Dixit, Biofuels 7, 537 (2016)

6. M. M. Rahman, H. H. Masjuki, M. A. Kalam, A. Atabani (A.E. Atabani), M. Shahabuddin, S. M. Palash, and M. A. Hazrat, Renew. Sustain. Energy Rev. 28, 441 (2013)

7. G. Knothe, L. F. Razon, D. A. Madulid, E. M. G. Agoo, and M. E. G. de Castro, Biofuels 9, 449 (2018)

8. E. G. Giakoumis, C. D. Rakopoulos, A. M. Dimaratos, and D. C. Rakopoulos, Prog. Energy Combust. Sci. 38, 691 (2012)

9. S. Saravanan, G. Nagarajan, G. L. N. Rao, and S. Sampath, Energy (Oxford) 35, 94 (2010)

10. A. Abu-Jrai, J. A. Yamin, A. H. Al-Muhtaseb, and M. A. Hararah, Chem. Eng. J. 172, 129 (2011)

11. W. Golimowski, P. Krzaczek, D. Marcinkowski, W. Gracz, and G. Wałowski, Sustain. 11, (2019) 